К. А. Качайло, Т. М. Мішеніна

\title{
ДИДАКТИЧНИЙ СУПРОВІД У ПРОЦЕСІ ВИВЧЕННЯ СЛОВОТВІРНОГО ПОТЕНЦІАЛУ НЕВІДМІНЮВАНИХ ІМЕННИКІВ У ЗМІСТІ КУРСУ «СУЧАСНА УКРАЇНСЬКА ЛІТЕРАТУРНА МОВА»
}

Качайло К. А., Мішеніна Т. М. Дидактичний супровід у процесі вивчення словотвірного потенціалу невідмінюваних іменників у змісті курсу «Сучасна українська літературна мова».

У статті здійснено спробу розроблення дидактичного супроводу у вивченні словотвірного потенціалу невідмінюваних імен у змісті навчальної дисципліни «Сучасна українська літературна мова». Система пропонованих завдань спрямована на вивчення словотвірного потенціалу невідмінюваних іменників за напрямками: 1) особливості входження невідмінюваних імен до словотвірної системи української мови; 2) розгляд невідмінюваних імен як словотвірної бази для суфіксальних одиниць; 3) невідмінювані іменники як компоненти складних слів.

Ключові слова: невідмінювані слова, дериват, словотвірний потенціал, майбутні вчителі філологічних спеціальностей.

Качайло К. А., Мишенина Т. М. Дидактическое сопровождение в процессе изучения словообразовательного потенциала несклоняемых имен существительных в содержании курса «Современный украинский литературный язык».

В статье сделана попытка разработки дидактического сопровождения при изучении словообразовательного потенциала несклоняемых существительных в содержании учебной дисциплины «Современный украинский литературный язык». Система предложенных заданий направлена на изучение словообразовательного потенциала несклоняемых существительных по направлениям: 1) особенности вхождения несклоняемых слов в словообразовательную систему украинского языка; 2) рассмотрение несклоняемых существительных как словообразовательной базы для суффиксальных единиц; 3) несклоняемые существительные как компоненты сложных слов.

Ключевые слова: несклоняемые слова, дериват, словообразовательный потенциал, будущие учителя филологических специальных.

Kachajlo K. A., Mishenina T. M. Didactic support in the study of potential slovotvoobrazovatelnogo indeclinable noun in the context of the course «Contemporary ukrainian literature language».

The article is an attempt to develop a didactic support in the study of word-formation potential of indeclinable nouns in the maintenance of discipline «Modern Ukrainian literary language». The system proposed by the task aims to explore the potential of word-formation indeclinable nouns following areas: 1) the particular entry indeclinable words in the wordformation system of the Ukrainian language, and 2) consideration of indeclinable nouns as the formative basis for suffixed units, and 3) indeclinable nouns as components of compound words.

Key words: indeclinable words, derivative, word-formation potential, future teachers of philology special.

У сучасному мовознавстві невідмінюваними іменами називають слова з сукупністю омонімічних словоформ, які мають нульові флексії $\mathrm{i}$ 
утворюють нульовий тип відмінювання.

Підклас невідмінюваних імен нині охоплює найрізноманітніші угруповання слів, кількісний і якісний склад яких неоднозначно кваліфікують в українській лінгвістиці [1, с. 11-14; 2, с. 89; 5, с. 324; 6, с. 123]. На окремий науковий розгляд заслуговують невідмінювані імена іншомовного походження, процес запозичення яких досить активізувався останніми десятиліттями.

Одним 3 актуальних питань у вивченні невідмінюваних імен іншомовного походження $є$ 3'ясування напрямків їх змін під впливом мови-реципієнта, пристосування до системи цієї мови (С. Авдєєва, Б. Ажнюк, В. Аристова, О. Безпояско, К. Городенська, О. Муровцева, В. Русанівський, В. Сімонюк, Ф.Філін та інші).

Показником високого рівня освоєння іншомовних слів i невідмінюваних імен системою мови $є$ участь їх у словотвірних процесах, тобто утворення дериватів і словотвірних гнізд за законами мови-реципієнта.

У процесі вивчення словотвірного потенціалу невідмінюваних іменників виокремлюємо напрямки: 1) особливості входження невідмінюваних імен до словотвірної системи української мови; 2) розгляд невідмінюваних імен як словотвірну базу для суфіксальних одиниць; 3) невідмінювані іменники як компоненти складних слів.

Вимоги, що висуваються до змісту науково-дослідницької роботи студентів, зумовлені фаховоим спрямуванням усіх видів навчальнопізнавальної діяльності з напряму підготовки - філологія: 1) структурування теоретичного матеріалу має забезпечувати досягнення мети фахової підготовки, зміст якої послідовно обгрунтовано у кваліфікаційних характеристиках, сприяти усвідомленню прикладного значення навчальної дисципліни для майбутнього фаху; 2) змістовне наповнення досліджуваного матеріалу має бути методологічним, що є засобом вироблення узагальнених умінь і навичок; 3) теоретична частина фахової навчальної дисципліни має містити фундаментальне ядро знань, що сприятиме формуванню у студентів наукової картини світу і сучасної методології іï пізнання; 4) розроблення завдань науково-дослідницької роботи студентів варто формулювати в контексті майбутнього фаху, що сприятиме розумінню й усвідомленню логічної моделі об’єкта дослідження.

Окреслені вимоги до науково-дослідницької роботи уможливлюють: урахування варіативних досліджень, які виходять за межі дидактично обробленої наукової галузі; використання науково-дослідницької діяльності майбутніх фахівців як системоутворювальної соціокультурної детермінанти становлення особистості студента - майбутнього фахівця високого рівня.

Мета статті - розробити дидактичний супровід у вивченні словотвірного потенціалу невідмінюваних імен у змісті навчальної дисципліни «Сучасна українська літературна мова».

(ㄱ К. А. Качайло, Т. М. Мішеніна, 2013. -695- 
Невідмінювані імена становлять підклас слів, який постійно поповнюється за рахунок запозичень 3 інших мов або дериватів, що конституюються на власній лексичній базі. Більшість із невідмінюваних субстантивів та ад'єктивів закінчується на голосний (авізо, бордо, доміно, драже, індиго, какаду, піке, хакі тощо). Невластивий українським питомим основам фонетичний кінець таких імен ускладнює словотворення від них. Пристосування невідмінюваних імен до законів українського словотворення здійснюється так, щоб їхні основи набули фонетичного оформлення, властивого українським іменним основам, тобто закінчувалися на приголосний шляхом: 1) усіченням кінцевої голосної невідмінюваного слова; 2) інтерфіксації [й], [т], [н], [с].

Методично доцільним у процесі спостереження над мовним матеріалом є завдання: Утворити від наведених іменників прикметники, зробити висновок про шляхи утворення: авізо, Батумі, Калахарі, Кіото, жалюзі, желе, купе, піке, шосе, комільфо, пушту, дао.

Наводимо приклади утворення похідних від невідмінюваних імен: авізо - авіз-н(ий); Батумі - батум-ськ(ий); Калахарі - калахар-ськ(ий); Кіліманджаро - кіліманджар-ськ(ий); Кіото - кіот-ськ(ий); кепі - кеп-

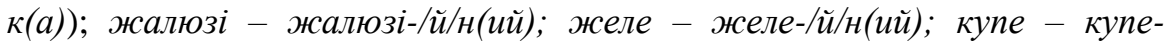
/ü/н(ий); піке - піке-/й/н(ий); шосе - шосе-/й/-н(ий); комільфо - комільфо$/ m /$ (ий); пушту - пушту-/н/ськ(ий); дао - дао-/с/зим).

У процесі словотворення похідних від невідмінюваних імен спостерігаються різноманітні морфонологічні перетворення, які трансформують твірну основу в похідну або модифікують дериваційний суфікс. Аналіз морфонологічної структури дериватів, твірною основою яких $\epsilon$ невідмінювані імена іншомовного походження, дозволяє виокремити такі основні комплексні морфонологічні перетворення:

1) усічення (елізія) твірної основи паралельно 3 акцентною альтернацією (з кореня твірної основи наголос пересувається на дериваційний суфікс (плаке́ - плакува́ти);

2) усічення твірної основи паралельно з акцентною альтернацією та інтерфіксацією (Пуерто-Ри́ко - пуерторик-/а́н/ець);

3) інтерфіксація та акцентна альтернація (Перу - перу-/ан/ець).

Дидактичний супровід передбачає такі тактики вивчення навчальної проблеми:

Порівняйте наведені словотвірні ланцюжки, прокоментуйте морфонологічні перетворення: 1) карате́ - карати́ст; мо́рзе -морзи́ст; плісе́ - плісирува́ти; Гайті - гаїтя́нин; Таїті - таїтянин; букле́ букльо́ваний; со́ло - соліст; 2) Пуерто-Ри́ко - пуерторик-/а́н/еиьв; Маро́кко-марокк-/áн/ець, Баки́-бак-/и́н/ецьь.

Однією 3 характерних особливостей входження невідмінюваних імен до словотвірної системи сучасної української мови $є$ вплив їхньої 
семантики на словотвірні можливості слова. Суть дериваційного процесу з семантичного погляду полягає в семантичному нарощенні, оскільки семантика більшості похідних слів не є сукупністю значень твірних основ і формантів.

Для невідмінюваних імен, за нашими спостереженнями, характерні семантичні зрушення, пов'язані 3 транспозицією (утворення від невідмінюваних іменників прикметників на -овиц̆, -ний); утворення від невідмінюваних субстантивів внаслідок черезступеневого словотворення іменників на -ння, -їзація та дієприкметників на -аний.

Завдання на спостереження над дериваційним процесом: Ymворіть від наведений невідмінюваних імен похідні, подайте коментар щуодо явищуа транспозиції: а) іменник - прикметник; б) іменник - іменник / дієприкметник за семантикою «дія».

Наводимо словотвірні ланцюжки: а) бароко - бароковии; піке пікейний; індиго - індиговий; інкасо - інкасовий; квебрахо - квебраховий; манго - манговии; праліне - праліновии; реле - релейний; сальдо - сальдовий; соло - сольний; б) відео - відеоїзація, євро - євроӥзація, табу - табуйований, букле -букльований, таксі- таксування.

Розгляд невідмінюваних імен як словотвірної бази для суфіксальних одиниць передбачає насамперед спостереження над суфіксальними дериватами (відсубстантивні суфіксальні прикметники, іменники та складні слова), що є найбільш розгалуженою і досить активною ділянкою словотвірної системи сучасної української мови.

У межах загального словотвірного значення «носій предметної ознаки» виокремлююється група дериватів - назв осіб, сформована на основі відіменникових словотвірних типів 3 питомими суфіксами -ещ̧ь, -анин і запозиченим формантом -icm/-ucm, що мають різний ступінь продуктивності: 1) досить продуктивними є похідні іменники із суфіксом -ець, що називають осіб за територіальною та національною ознакою (адигеєu̧ь, малієuь); 2) порівняно меншу кількість похідних іменників із цим значенням утворено за допомогою суфікса -анин (-янин): гаїтянин, таїтянин, що зумовлено його історичним функціонуванням; 3) високою продуктивністю характеризується словотвірний тип відіменних дериватів із суфіксом -icm/-ucm, що вживається на позначення осіб за їхнім стосунком до певної сфери діяльності (cамбіст, coліст).

Активність виявляють також відсубстантивні деривати словотвірного типу із суфіксом -ізм/-изм, уживані в найменуваннях, що вказують на стосунок до певної суспільної категорії чи політичної партії (торизм, дендизм).

Значну групу відіменникових похідних становлять ад'єктиви словотвірного типу із суфіксом -сbк-/-цьк-, коло твірних основ яких об'єднує власні і загальні назви (адигейський, перуанський, бордоський).

Найпоширенішими дієслівними словотворчими афіксами, активність вживання якого дедалі зростає [4, с. 194], є суфікс -ува- (-юва-), меншу продуктивність має суфікс -ірува-/-ирува-. Суфікси поєднуються з різними (C) К. А. Качайло, Т. М. Мішеніна, 2013. -697- 
невідмінюваними іменами і виражають такі словотвірні значення: 1) «перетворювати на те, що визначає твірний невідмінюваний іменник»: травестувати, зомбувати; 2) «робити, створювати те, на що вказує твірний невідмінюваний іменник»: декольтувати, дражсирувати, крокіювати, плісирувати.

Методично доцільними є такі завдання:

1. Відтворіть словотвірний ланцюжок, зробіть висновок про продуктивність словотворчого афікса, прокоментуйте семантичні нашарування: самбіст, соліст, есперантист, каратист, лібретист, піаніст, таксист, дербіст, дзюдоїст, раліст, есеїст, кантеліст.

2. Відтворіть словотвірний ланцюжок, продовжте ряд (5 прикладів), користуючись Словником географічних назв: мансієц̧ь, марієц̧ь, марокканец̧ь, перуанець, пуерториканецьь, сомалієць, удигеєць, уланудинецьь.

3. Утворіть від невідмінюваних іменників на позначення топонімів та народностей похідні іменники із суфіксом -ецьь - назви осіб чоловічої статі, відносні прикметники на -ськ(uй).

Зразок: Зімбабве - зімбабвієизь, зімбабвійський; Конго - конголезецьь, конголезький; зулу - зулус, зулуський; Малі-малієць, малійський; Марокко марокканець, марокканський; Нікарагуа - нікарагуанецьь, нікарагуанський; Перу - перуанець, перуанський; Пуерто-Рико - пуерто-риканець, пуерториканський; Фіджі-фіджієцьь, фіджійський; Чилі-чилієцьь, чилійський.

4. Утворіть від іменників чоловічого роду утворилися субстантиви жіночого роду із суфіксом -к-.

Зразок: зімбабвієць - зімбабвійка; конголезещь - конголезка; зулус зулуска; малієць - малійка; мансієц̧ь - мансійка; марієць - марійка; марокканець - марокканка; нікарагуанець - нікарагуанка; перуанець перуанка; пуерториканець - пуерториканка; сочинець - сочинка; таїтянець таїтянка; удегеєизь - удегейка; фіджієизь - фіджійка; чилієиьь - чилійка.

5. Відтворіть словотвірний ланцюжок. Подайте значення суфіксальних дериватів: торизм, дендизм, макіавеллізм, лобізм, джингоїзм.

6. Відтворіть словотвірний ланцюжок. Розмежуйте твірні основи на власні i загальні, зробіть висновок про їх словотворчий потенціал: адигейський, перуанський, бордоський, гельсінський, есперантський, зулуський, альма-материнський, делійський, уланудинський, сомалійський, калахарський, малійський, сочинський, сухумський.

7. Відтворіть словотвірний ланцюжок. Подайте коментар, які словотвірні значення виражають суфікси: травестувати, бомбувати, декольтувати, дражирувати, крокіювати, плісирувати.

Невідмінювані іменники можуть становити компоненти складних слів. Юкстапозити передають нові поняття, зв'язок між компонентами яких є вільним, тобто сама модель побудови не передбачає морфонологічних змін у структурі їі складників, що сприяє широкому використанню невідмінюваних 
іменників іншомовного походження для творення складних лексичних одиниць: кафе-бар, кафе-кондитерська, інтернет-кафе, иоу-вікторина, шоу-театр, иоу-програма, шоу-балет, шоу-зірка, медіа-простір, медіапереворот, медіа-магнат, медіа-барон, медіа-ресурс.

Регулярність складників відео, аудіо, кіно, шоу, медіа в поєднанні 3 іменниками переконує в специфічності складання як способу творення слів, що $є$ свідченням розвитку словотвірної системи сучасної української мови, взаємодії одноосновної і багатоосновної деривації. Поширеність аглютинативних основ як засобу словотворення нових дериватів дає підстави зробити припущення про становлення нового способу формування похідних - за допомогою регулярних самостійних невідмінюваних іменників.

За нашим спостереженням, інтернаціональні компоненти відео, кіно, aydio набули активності у словотворенні, передусім у складанні, внаслідок зростання ролі кінематографії і технічних засобів масової інформації. Аглютинативний компонент кіно, поєднуючись 3 іменниками, може виражати значення: а) прикметника кінематографічний (кіноматеріал); б) називати жанр кінофільму (кінобойовик, кіносеріал, кіногазета); в) предмети i явища, пов'язані зі створенням i прокатом фільмів (кіномістечко, кіноспоруда); г) осіб (кінопоет).

Бурхливий розвиток відеотехніки, потреба у зв'язку з цим у нових номенах зумовили словотвірну активність латинської за походженням основи відео (з лат. - дивлюся, бачу). Відповідно, основа відео у структурі кількох слів відеотелефон, відеограма, відеорекордер, відеосигнал, відеофонограма [7, с. 127] стає згодом більш продуктивною: з'являються дво- і трикомпонентних похідних із цією основою

Основа відео входить до складу назв: а) технічних засобів для знімання i відтворення відеозапису (відеоапаратура, відеоплейєр, відеотехніка); б) назв приміщень і закладів для створення і демонстрації відеопродукції (відеобар, відеозал, відеокабіна, відеооб'єднання, відеоцентр); в) назв видів відеопродукції (відеоматеріал, відеотижневик).

Засвідчуємо словотвірну активність основи латинського походження aydio, семантика якої пов'язана зі слуховим сприйняттям інформації, музики: аудіопродукція, аудіоапаратура, аудіокасета, аудіокомпанія, аудіоновинка, аудіозапис, аудіотехніка тощо.

Позамовним чинником поширення складних слів 3 невідмінюваним іменником $\epsilon$ надходження запозичень певної семантики до певних мовленнєвих сфер: мас-медіа: медіа-видавецьь, медіа-nрофi, медіа-група, медіа-проект, медіа-імперія.

Залежно від ступеня цілісності оформлення компонентів юкстапозити поділяємо на дві групи: 1) складні слова, у яких обидва компоненти невідмінювані (мецо-форте); 2) складні слова, у яких один компонент відмінюване слово, а інший - невідмінюване (иоу-дійство).

(ㄱ К. А. Качайло, Т. М. Мішеніна, 2013. - 699- 
Деривати субстантива кіно (від грец. рухаю) становлять складні слова, серед яких констатовано: іменники (кіноакадемія, кіноаматор, кіноархів); прикметники (кінознімальний, кінокопіювальний).

Наводимо орієнтовні приклади завдань, спрямованих на вивчення словотворчого потенціалу невідмінюваних імен:

1. Відтворіть словотвірний ланцюжок. Розмежуйте деривати за групами: а) складні слова, у яких обидва компоненти невідмінювані; б) складні слова, у яких один компонент відмінюване слово, а інший невідмінюване. Зробіть висновок про частотність уживання юкстапозитивів в сучасній українській літературній мові: мещо-сопрано, міді-мода, кабаре-дует, сальто-мортале, шоу-дійство, максі-спідниия, нетто-маса, шоу-ицентр.

2. Проаналізуйте подане словотвірне гніздо. Виокремте словотвірні ланцюжки. Зразок: кіно $\rightarrow$ кіноактор $\rightarrow$ кіноакторський; кіно $\rightarrow$ кіноактриса $\rightarrow$ кіноактрисочка; кіно $\rightarrow$ кінодраматургія $\rightarrow$ кінодраматургічний; кіно $\rightarrow$ кінолітопис $\rightarrow$ кінолітописецьь; кіно $\rightarrow$ кінолітопис $\rightarrow$ кінолітописний; кіно $\rightarrow$ кінопрокат $\rightarrow$ головкінопрокат; кіно $\rightarrow$ кінопрокат $\rightarrow$ кінопрокатний.

3. Розмежуйте частиномовну належність наведених дериватів. Виокремте тематичні групи.

Кінобойовик, кіноафіша, кіновипуск, кіновиробництво, кіноглядач, кінодокументаліст, кінодраматург, кінознімальний, кінокопіювальний, кіноекран, кіножурнал, кінозал, кіноіндустрія, кіноказка, кінокартина, кінокласика, кіноклуб, кінокомпанія, кінолегенда, кіноматеріал, кіномистецтво, кінопанорама, кінопромисловість, кінороман, кінопроекиійний, кінотелевізійний.

У словотвірному гнізді іменника бюро (від франц. bureau - бюро) переважають складноскорочені слова (абревіатури) мішаного типу: гідрометеобюро, екскурсбюро, інформбюро, машбюро, партбюро, профбюро.

Похідні невідмінюваного іменника кафе становлять складні іменникиюкстапозити: кафе-автомат, кафе-бар, кафе-кондитерська, кафеморозиво, Інтернет-кафе, магазин-кафе.

Подібну структуру має словотвірне гніздо з вершинним словом медіа, у якому серед похідних, за матеріалами преси, переважають юкстапозити, що утворюються на першому дериваційному ступені: медіа-барон, медіаресурс, медіа-переворот, медіа-проект, медіа-імперія.

Методично доцільними будуть такі завдання:

1. Утворіть від невідмінюваного іменника бюро складноскорочені слова (абревіатури) мішаного типу. Розкрийте їх значення. Гідро-, мете-, екскурсія, інформачія, партія.

2. Утворіть юкстапозитиви від іменника кафе. Поясніть їх правопис. Спрогнозуйте можливі варіанти утворення юкстапозитивів у сучасній 
українській літературній мові: Автомат, бар, кондитерська, морозиво, Інтернет, магазин.

На окремий розгляд заслуговує питання тематичного розшарування дериватів унаслідок полісемії твірної основи.

Зокрема, як зазначено у «Словнику української мови», слово padio $^{1} \epsilon$ багатозначним: 1) передавання на відстань без дротів інформації за допомогою радіохвиль; 2) те саме, що радіопередача; 3) те саме, що радіоприймач; 4) центр, звідки ведеться радіопередача [3, т. 8, с. 430]. Як перша частина складних слів, що відповідає слову радіо у 1 значенні, входить до композитів: радіоавтограф, радіоаеронавігащійний, радіоаеронавігащія, радіоакумулятор, радіоакустичний, радіовишка, радіолабораторія, радіолінія, радіообмін, радіообслуговування, радіооператор, радіопеленгування, радіорефлектор, радіосправа, радіотелескопія, радіочастота; 2 значення реалізоване у словах: радіовиступ, радіожурнал, радіоінформачія, радіолекторій, радіолекція, радіоматч, радіомітинг, радіоогляд, радіоповідомлення, радіопрогноз, радіорозвідка, радіоспектакль, радіотеатр, радіошуми; 3 значення - у словах: радіовиробництво, радіодеталь, радіозавод, радіоелемент, радіомайстерня, радіопересувка, радіотовари, радіоустановка, радіоустаткування ; радіо ${ }^{2}$ - перша частина складних слів, що відповідає слову радіоактивний, напр.: радіоізотоп, paдіойод, радіолікування, радіоскопія, радіострониій, радіо фосфор.

Спостереження над мовним матеріалом передбачає такі завдання:

1. Випишіть зі Словника української мови деривати від твірної основи padio. Розмежуйте деривати за такими групами: 1) передавання на відстань без дротів інформації за допомогою радіохвиль; 2) те саме, що радіопередача; 3) те саме, що радіоприймач. Зробіть висновок про системні відношення в межах термінів з основою радіо.

2. Розмежуйте деривати за поданими тематичними групами. Зробіть висновок про семантичні нашарування у структурі термінів: 1) прилади $\check{u}$ апарати; 2) комплексні, узагальнювальні поняття; 3) наукові галузі та їхні підрозділи; 4) технічні галузі та їхні підрозділи процеси та явища; особи за фахом чи виконуваною роботою.

Радіопеленгатор, радіологія, радіотехніка, радіоелектроніка, радіостаниія, радіопрожектор, радіолокачія, радіослухачка, радіотехнік, радіопеленгачія, радіоімпульс, радіокомпаратор, радіокомпас, радіотелескоп, радіозонд, радіовисотомір, радіотехніка, радіофонія, радіолуна, радіомутаиії, радіохвиля, радіоаматор, радіокоментатор, радіолюбитель, радіометрист, радіомонтер, радіонавігатор, радіослухач, радіофікатор.

3. Наведіть терміни-відповідники до наведених словникових статей 3 компонентом padio. Визначте їх тематичну групу: телеграма, що передається по радіотелеграфу (радіотелеграма); відомості, одержані внаслідок перехоплення передач противника (радіоперехоплення); галактика, ๑ К. А. Качайло, Т. М. Мішеніна, 2013. 
потужність випромінювання якої приблизно дорівнює потужності ऑiі випромінювання в оптичному діапазоні довжин хвиль (радіогалактика); назва джерел космічного радіовипромінювання 3 малими кутовими розмірами (радіозірки); установа, яка здійснює передавання і приймання радіоповідомлень, радіовистав, радіоконцертів (радіостанція); установа, яка здійснює телеграфний зв'язок по радіо (радіотелеграф).

4. Поясніть значення дериватів із компонентом радіо за зразком стосунок до того, щзо позначає основа: радіоавтографічний, радіоаматорський, радіоастрономічний, радіобіологічний, радіовимірювальний, радіоелектронний, радіолокачуійний, радіолюбительський, радіомовний, радіонавігаційний, радіопеленгаторний, радіоприймальний, радіорелейний, радіотелеметричний, радіотерапевтичний, радіотрансляційний.

5. Утворіть терміни, що позначають властивості, якості. Напр.: радіоактивний - який має радіоактивність: а) який уловлює, перетворює $i$ використовує енергї радіохвиль; б) який здійснюється за допомогою передавання сигналів надвисокої частоти через проміжні приймальнопередавальні радіостаниії.

6. Утворіть терміни з компонентом радіо. Розкрийте закономірність розвитку терміносистеми залежно від розвитку відповідної науки: азот, торій, фосфор, актиній, вуглецьь.

7. Проаналізуйте пропоновані національні відповідники до другої частини іншомовного слова. Зробіть висновок про доречність і точність взаємозаміни. Чи можна наведені терміни кваліфікувати як абсолютні синоніми?

Радіоінформація - радіовідомість, радіопеленгатор - радіовизначник, радіорепродуктор - радіовідтворювач, радіосигнал - радіогасло, радіотерапія - радіолікування, радіотрансляціія - радіопередача, радіальний променевий (за П. Штепою);

Радіація - променевість, промінність, променювання; радіоактивність променистість, випромінність, променездатність, променетворчість; радіолокатор - радіознахідник; радіопрожектор - радіовисилач, радіорозвідка - радіорозвідунство, радіорупор - радіогучень, гучномовець, радіочутливість - променечутливість, променечуйність, радіошум радіогуд, радіогалас (за М. Вакуленком).

Словотвірна активність запозичених невідмінюваних лексем, їх здатність бути твірною основою для похідних слів, поєднання 3 афіксами мови-реципієнта $є$ одним із показників укорінення таких запозичень в українській мові. Обмежені словотвірні можливості невідмінюваних імен спричинені належністю їх до терміносистем, що характеризуються вузькостилістичним функціонуванням, належністю до якоїсь лексикотематичної групи тощо. Певну роль відіграють морфонологічні явища, пов'язані з обмеженням поєднувальних можливостей суфіксів у творенні 
похідних від невідмінюваних імен, зумовлені намаганням уникнути небажаних мовних явищ, незвичного звукового оформлення слів.

Науково-дослідницька діяльність студентів в умовах ВПНЗ дозволяє визначити зміст предметної компетентності в опануванні конкретною науковою галуззю: уміння застосовувати адекватний методологічний апарат дослідження; уміння аналізувати інформаційні джерела щодо досліджуваного питання; уміння застосовувати технологію наукового дослідження.

Визначаємо перспективність тенденції переструктурування змісту навчальних курсів, розробивши відповідно до освітньо-професійного напряму фундаментальні і спеціальні завдання науково-дослідницької діяльності; передбачити збільшення частки профільних завдань із виразно прикладним характером науково-дослідницької діяльності, пов'язаної зі специфікою майбутньої професійної діяльності; вивчення методологічних особливостей, визначальних у формуванні наукового мислення майбутнього фахівця.

\section{Література}

1. Авдєєва С. Л. Нульова парадигма в сучасній українській літературній мові / С. Л. Авдєєва // Лінгвістичні студії : зб. наук. праць. - Донецьк : ДонНУ, 2003. Вип. 11. - Част. 1. - С. 11-20.

2. Безпояско О. К. Граматика української мови : Морфологія / О. К. Безпояско, К. Г. Городенська, В. М. Русанівський. - К. : Либідь, 1993. - 335 с.

3. Жлуктенко Ю. О. Мовні контакти / Ю. О. Жлуктенко. - К. : Вид-во Київ. ун-ту, 1966. $-135 \mathrm{c}$.

4. Русанівський В. М. Структура українського дієслова / В. М. Русанівський. - К. : Наук. думка, 1971. - 315 с.

5. Сучасна українська літературна мова / за ред. А. П. Грищенка. - К. : Вища школа, 2002. - 439c.

6. Сучасна українська літературна мова : Лексика і фразеологія. - К. : Наук. думка, 1973. - 438 с.

7. Словник іншомовних слів. - К. : Головна редакція УРЕ, 1985. 